(C) 2013

Філоненко С. В., кандидат сільськогосподарських наук

Полтавська державна аграрна академія

\title{
ФОРМУВАННЯ ЗЕРНОВОЇ ПРОДУКТИВНОСТІ КУКУРУДЗИ ЗА РІЗНИХ СПОСОБІВ ОСНОВНОГО ОБРОБІТКУ ГРУНТУ
}

\section{Рецензент - кандидат сільськогосподарських наук Н. С. Шокало}

\begin{abstract}
Викладені результати досліджень особливостей формування зернової продуктивності кукурудзи гібриду PR39R86 за різних способів основного обробітку грунту, щзо поширені у зоні недостатнього зволоження Лівобережного Лісостепу. Встановлено: саме за чизельного способу основного обробітку, шуо виконується на глибину 37-40 см, відмічається більш глибоке зволоження трунту під час весняного танення снігу і покрашусться в зв'язку з цим вологозабезпеченість культури у другій половині вететації. Все це в кінцевому результаті сприяє оптимізації умов росту і розвитку рослин кукурудзи, особливо за несприятливого посушливого літнього періоду.
\end{abstract}

Ключові слова: спосіб обробітку, кукурудза, густота рослин, площяа листків, біологічна врожайність, зернова продуктивність, маса поча$m \kappa y$.

Постановка проблеми. Відомо, що висока продуктивність будь-якої культури, в тому числі й кукурудзи, головним чином залежить від технології їі вирощування, основною складовою якої $є$ правильно підібрана система обробітку грунту.

Вчасно й якісно виконаний та правильно підібраний обробіток грунту сприяє окультуренню орного шару, поліпшує водно-повітряний, тепловий і поживний його режими для вирощування сільськогосподарських культур. За допомогою обробітку регулюють агрофізичні, біологічні та агрохімічні процеси, що відбуваються в грунті, інтенсивність розкладання i нагромадження органічної речовини, грунтової вологи у кореневмісному шарі й ефективність використання внесених добрив.

Загальновідомо, що обробіток грунту - один iз найефективніших заходів боротьби 3 бур'янами, шкідниками та хворобами сільськогосподарських культур.

Сьогодні на виробництві допоки відсутня чітка позиція щодо застосування того чи іншого способу основного обробітку грунту під сільськогосподарські культури, в тому числі й під кукурудзу. Виходячи 3 цього, дослідження щодо впливу основного обробітку грунту на врожайність кукурудзи є досить важливими і не втрачають своєї актуальності. Саме цим й обумовлено проведення даних досліджень.

Аналіз основних досліджень і публікацій, у яких започатковано розв'язання проблеми. Обробіток грунту - важлива складова сучасного землеробства. Нині цьому питанню надається чимало уваги. Зокрема фахівці аграрного сектора активно обговорюють переваги та недоліки полицевого й безполицевого, глибокого і мілкого, поверхневого обробітків грунту та нової енергоощадної технології прямого висіву (no-till) [7].

За оранки глибоке розпушення передує напівпаровому обробітку, що призводить до небажаного ущільнення розпушеного шару. Така схема обробітку, як запевняють Ф. М. Архипенко, О. О. Артюшенко та П. І. Кухарчук (2005), зумовлює один із основних недоліків напівпару на фоні оранки - зниження протиерозійної стійкості грунту. Щоб цього уникнути, напівпаровий обробіток доповнюють плоскорізним розпушуванням на глибину 14-16 см [1].

Наукові дослідження i виробничий досвід свідчать про те, що сучасним вимогам найповніше відповідають різні прийоми обробітку полицевими i безполицевими знаряддями. Використання кількох типів знарядь основного обробітку плугів, плоскорізів, чизелів, діагональних розпушувачів, дискових лущильників і борін, важких культиваторів, допоміжних до них пристроїв передбачає застосування значної кількості поєднань їх у сівозмінах у процесі вирощування окремих зернових культур, у тому числі й кукурудзи на зерно [3].

За рівної агротехнічної ефективності полицевого і безполицевого обробітку у Степу і на землях Лісостепу перевагу має безполицевий обробіток, який забезпечує підвищення протиерозійної стійкості грунту. Однакова ефективність оранки та прийомів безполицевого обробітку під кукурудзу, впевнений С. Г. Танчик (2003), спостерігається, як правило, тільки в перший рік іiі вирощування, у наступні - 
відмічається перевага оранки [5].

Нині класичний плужний обробіток у, так би мовити, чистому вигляді в Україні ніде не запроваджується. Звичайно, сьогодні - це диференційований обробіток у сівозмінах, коли під окремі культури здійснюється оранка, дисковий, плоскорізний, чизельний обробіток у межах від 6-8 до 40-45 сантиметрів.

Порівняльне вивчення всіх систем обробітку грунту свідчить про майже однаковий їх вплив на формування урожайності польових культур. Відміни між ними, як доводить О. М. Бовсуновський (2008), знаходяться зазвичай у межах $2 \%$. Нині, коли живлення рослин регулюється головним чином застосуванням добрив, регуляторами росту рослин, боротьбу з бур'янами покладено на гербіциди, а хвороби та шкідливі ентомологічні об'єкти також контролюються фунгіцидами та інсектицидами, роль обробітку значно змінилася. Вона змістилася в сторону організаційних проблем, зокрема підвищення продуктивності праці, охорони грунтів від ерозії, дефляції, раціонального використання водних ресурсів, покращання рекреаційних властивостей ландшафтів [2].

У районах достатнього зволоження, як відмічають вчені, із сумою опадів до 600 мм, на сірих лісових грунтах кукурудза позитивно реагує на неглибоку оранку (10-12 см). За ротацією семипільної сівозміни у довготривалому досліді на сірому лісовому грунті після неглибокої оранки врожайність зерна кукурудзи становила 51,4 ц/га, по оранці на 25-27 см 49,4 ц/га [6].

Попередні дані досліджень численних науковців свідчать про високу ефективність чизельного розпушування на глибину до 45 см під кукурудзу 3 руйнуванням плужної «підошви». За цього обробітку відмічається більш глибоке зволоження грунту під час весняного танення снігу і поліпшення в зв'язку з цим вологозабезпеченості культури у другій половині вегетації. Особливо ефективний цей прийом на схилах до $5^{0}$, де він повністю виключає стік талої води. Енергоємність та якість роботи чизельних робочих органів значною мірою визначається глибиною обробітку грунту та відстанню між ними [4].

Отже, система обробітку грунту в технології вирощування будь-якої культури, в тому числі й кукурудзи, займає чільне місце, тому питання іiі оптимізації є досить важливим. Наразі існує ціла низка даних про ефективність різних способів основного обробітку грунту під цю культуру. Саме розбіжність поглядів і висновків численних дослідників щодо впливу цих способів обробітку на зернову продуктивність кукурудзи свідчить про те, що дане питання $\epsilon$ ще недостатньо вивченим.

Мета досліджень - вивчення впливу різних способів основного обробітку грунту, що поширені в зоні недостатнього зволоження Лівобережного Лісостепу, на зернову продуктивність кукурудзи у виробничих умовах.

\section{Завдання дослідження:}

1. Дослідити вплив різних способів основного обробітку грунту на зернову продуктивність кукурудзи.

2. Встановити їх вплив на забур'яненість посівів культури.

3. Вивчити вплив способів основного обробітку грунту на динаміку росту та площу листкової поверхні рослин кукурудзи.

4. Встановити ступінь впливу агротехнічних заходів на елементи структури врожайності культури.

Методики проведення досліджень. Польові досліди проводили протягом 2011-2012 років у товаристві $з$ обмеженою відповідальністю «ЛанАгро» (директор - Писанка Олег Іванович, головний агроном - Філоненко Василь Миколайович) Глобинського району Полтавської області. Грунт дослідної ділянки - чорнозем глибокий залишково слабосолонцюватий із вмістом гумусу $3,8 \%$, pH грунтового розчину $-7,2$. Метеорологічні умови вегетаційних періодів у роки проведення дослідів значно відрізнялися від середніх багаторічних.

Об'єктом досліджень слугували поширені в області способи основного обробітку грунту. Предмет досліджень - рослини гібриду кукурудзи PR39R86 фірми «Pioneer A DuPont Company».

Дослідження проводили за такою схемою:

1. Дискування стерні на глибину $12-14$ см БДВ-7,0, культивації паровими культиваторами КПС-4 в міру відростання бур'янів - фон, оранка на глибину 28-30 см (вересень - початок жовтня) - контроль.

2. Фон + плоскорізний обробіток на глибину 28-30 см культиваторами-глибокорозпушувачами КПШ-5 (вересень - початок жовтня).

3. Фон + мінімальний обробіток на глибину 14-16 см БДВ-7,0 (вересень - початок жовтня).

4. Фон + чизельний обробіток на глибину $37-$ 40 см АПЧ-4,5 (вересень - початок жовТня).

Загальна площа ділянки у 2011 році становила 1,6 га, облікова - 1,2 га; у 2012 році, відповідно, 1,8 і 1,4 га. Повторність досліду триразова. Розміщення ділянок варіантів досліду 
- систематичне. Попередник кукурудзи - пшениця озима. Агротехніка вирощування кукурудзи на дослідних ділянках - загальноприйнята для відповідної грунтово-кліматичної зони (крім способів основного обробітку грунту). Врожай зерна визначали шляхом його зважування із кожної ділянки. Спостереження, аналізи та інші обліки проводилися у відповідності із загальноприйнятими методиками, розробленими вітчизняними науковцями.

Результати досліджень. У світовій практиці існує чимало даних стосовно значимості системи основного обробітку грунту та ii впливу на продуктивність сільськогосподарських культур і кукурудзи зокрема. Загальновідомо, що правильно підібраний спосіб основного обробітку грунту суттєво впливає на зниження рівня забур'яненості посіву культури. Саме тому про- грамою наших дослідів і передбачалося вивчити вплив відповідного чинника на забур'яненість посівів кукурудзи. Такі обліки проводили на дослідних ділянках у фазі стеблування культури. Це обумовлено тим, що перед сівбою, відповідно до загальноприйнятої у господарстві технології, вносили грунтовий гербіцид «Харнес». Дія цього препарату пригнічувала сходи бур'янів на початку вегетації кукурудзи, тобто за допомогою нього стримували першу хвилю бур'янів, що 3'являлася на посівах.

Із часом гербіцидна дія послаблювалась - i бур'яни розпочинали більш інтенсивно рости на дослідних ділянках. Саме тоді можна було вже чітко побачити, який iз способів основного обробітку грунту виявився ефективнішим стосовно зниження рівня забур'яненості посівів культури (табл. 1).

\section{1. Вилив способів основного обробітку трунту на забур'яненість посівів кукурудзи (фаза стеблування)}

\begin{tabular}{|c|c|c|c|c|c|c|}
\hline \multirow{2}{*}{ Варіанти досліду } & \multicolumn{6}{|c|}{ Показники } \\
\cline { 2 - 7 } & \multicolumn{2}{|c|}{ кількість бур'янів, шт./м² } & \multicolumn{3}{c|}{ маса бур'янів із 1 м², г } \\
\cline { 2 - 7 } & $2011 \mathrm{p}$. & $2012 \mathrm{p}$. & $\begin{array}{c}\text { середнє за } \\
\text { два роки }\end{array}$ & $2011 \mathrm{p}$. & $2012 \mathrm{p}$. & $\begin{array}{c}\text { середнє за } \\
\text { два роки }\end{array}$ \\
\hline $\begin{array}{c}\text { 1. Оранка на глибину 28-30 см } \\
\text { (контроль) }\end{array}$ & 50 & 22 & 36 & 42 & 18 & 30 \\
\hline $\begin{array}{c}\text { 2. Плоскорізний обробіток } \\
\text { на глибину 28-30 см }\end{array}$ & 145 & 69 & 107 & 65 & 39 & 52 \\
\hline $\begin{array}{c}\text { 3. Мінімальний обробіток } \\
\text { на глибину 14-16 см }\end{array}$ & 168 & 84 & 126 & 71 & 41 & 56 \\
\hline $\begin{array}{c}\text { 4. Чизельний обробіток } \\
\text { на глибину 37-40 см }\end{array}$ & 73 & 55 & 64 & 60 & 36 & 48 \\
\hline
\end{tabular}

\section{2. Вилив способів основного обробітку трунту на густоту рослин кукурудзи} (в середньому за 2010-2011 рр.)

\begin{tabular}{|c|c|c|c|c|}
\hline \multirow{2}{*}{ Показник } & \multicolumn{4}{|c|}{ Варіанти досліду } \\
\cline { 2 - 5 } & $\begin{array}{c}\text { 1) оранка } \\
\text { на глибину } \\
28-30 \text { см } \\
\text { (контроль) }\end{array}$ & $\begin{array}{c}\text { 2) плоскорізний } \\
\text { обробіток } \\
\text { на глибину } \\
28-30 \text { см }\end{array}$ & $\begin{array}{c}\text { 3) мінімальний } \\
\text { обробіток } \\
\text { на глибину } \\
14-16 \text { см }\end{array}$ & $\begin{array}{c}\text { 4) чизельний } \\
\text { обробіток } \\
\text { на глибину } \\
37-40 \text { см }\end{array}$ \\
\hline $\begin{array}{c}\text { Кількість висіяного насіння, } \\
\text { шт./м пог. }\end{array}$ & 6 & 6 & 6 & 6 \\
\hline $\begin{array}{c}\text { Кількість рослин за повних } \\
\text { сходів, шт./м пог. }\end{array}$ & 5,7 & 5,76 & 5,8 & 5,75 \\
\hline Польова схожість, \% & 95 & 96 & 96,7 & 95,8 \\
\hline Густота сходів, тис./га & 81,5 & 82,4 & 82,9 & 82,2 \\
\hline $\begin{array}{c}\text { Кількість рослин } \\
\text { перед збиранням, шт./м пог. }\end{array}$ & 5,5 & 5,4 & 5,3 & 79,5 \\
\hline $\begin{array}{c}\text { Густота рослин } \\
\text { перед збиранням, тис./га }\end{array}$ & 78,1 & 77,2 & 75,8 & 3,6 \\
\hline Зменшення густоти рослин, \% & 4,2 & 6,3 & 8,6 & 3,6 \\
\hline
\end{tabular}


Аналізуючи дані відповідної таблиці, можна відмітити, що найменше бур'янів на дослідних ділянках (у середньому за два роки) виявилося на варіанті з оранкою на глибину 28-30 см, що слугував контролем. У фазі стеблування кукурудзи на ділянках відповідно варіанту було, в середньому, 36 шт./м² бур'янів. Найбільше бур'янів у цей час виявилося на третьому варіанті, де проводився мінімальний обробіток важкими дисковими боронами на глибину $14-16$ см (126 шт./ м $\left.^{2}\right)$.

Чизельний обробіток (четвертий варіант) займає стосовно цього показника проміжне значення, тому що на його ділянках нарахували, в середньому за два роки, 64 шт./м² бур'янів. Продовжуючи аналізувати дані відповідної таблиці, варто звернути увагу на масу бур'янів, облік якої здійснювали водночас із обліком їх кількості.

Зауважимо, що маса бур'янів у цей період характеризувалася такою ж тенденційністю, як і їх кількість. Найбільша маса бур'янів $31 \mathrm{~m}^{2}$ за два роки, як і можна було сподіватися, виявлена на варіанті із мінімальним обробітком (варіант 3) - 56 г; мінімальну масу мали бур'яни на контролі (30 г).

Вплив способів основного обробітку грунту на густоту рослин кукурудзи характеризують дані таблиці 2.

Отже, відповідно до даних таблиці 2, можна iз впевненістю стверджувати, що способи основного обробітку грунту певною мірою впливають на густоту рослин і на їх збереження протягом вегетації. Відомо, що оптимальна система обробітку грунту здатна сприяти не тільки поліпшенню агрофізичних властивостей останнього, але й кращому накопиченню вологи опадів. Саме тому на варіанті, де вдалося більше накопичити вологи за осінній і весняний періоди і разом 3 цим сформувати оптимально розпушений орний шару грунту, найменше випало рослин протягом вегетаційного періоду.

Слід зазначити, що компанія «Pioneer A DuPont Company», яка $€$ оригінатором гібриду
PR39R86, рекомендує для нього дотримуватися густоти стояння рослин кукурудзи на рівні 76-81 тис./га. Саме тому у господарстві на площах, де вирощували цей гібрид, щорічно висівали по 6 шт. насінин на 1 метр рядка. Підрахунок рослин у фазі повних сходів показав, що таке насіння мало досить високі посівні властивості: в середньому за два роки на кожному погонному метрі ділянок варіантів досліду отримали в цей час практично однакову кількість рослин - по 5,7-5,8 шт./м погонний. Така кількість сходів відповідала рекомендованій оригінатором густоті рослин на гектарі (від 81,5 до 82,9 тис./га).

Оптимальні агрофізичні властивості грунту, а також достатня кількість продуктивної вологи, що накопичилася після застосування певних систем основного його обробітку, дали можливість рослинам кукурудзи на цих ділянках у повній мірі реалізувати свій продуктивний потенціал. До того ж тут і менше випадало щорічно рослин протягом вегетації.

Отже, найменше густота рослин кукурудзи на період збирання знизилася саме на варіанті, де проводився чизельний обробіток (3,6\%). Тому тут і виявилася, в середньому за два роки, максимальна кількість рослин культури перед збиранням (79,2 тис./га).

Друге місце за відповідними показниками зайняв контрольний варіант, де проводили оранку. На його ділянках густота рослин кукурудзи, в середньому за два роки, становила 78,1 тис./га, а протягом вегетації кількість її зменшилася всього на $4,2 \%$.

Найгірші умови за роки досліджень створилися для рослин культури протягом вегетаційного періоду саме після мінімального обробітку: на ділянках цього варіанту перед збиранням нарахували, в середньому, 75,8 тис. рослин кукурудзи, а відсоток біотипів, що випали, становив 8,6\%.

Дані таблиці 3 характеризують вплив способів основного обробітку на урожайність зерна кукурудзи.

3. Вилив способів основного обробітку трунту на врожайність зерна кукурудзи, ц/га

\begin{tabular}{|c|c|c|c|}
\hline \multirow{2}{*}{ Варіанти досліду } & \multicolumn{2}{|c|}{ Роки } & Середнє \\
\cline { 2 - 3 } & 2011 & 2012 & за два роки \\
\hline 1. Оранка на глибину 28-30 см (контроль) & 114,2 & 78,4 & 96,3 \\
\hline 2. Плоскорізний обробіток на глибину 28-30 см & 97,6 & 72,2 & 84,9 \\
\hline 3. Мінімальний обробіток на глибину 14-16 см & 88,6 & 62,0 & 75,3 \\
\hline 4. Чизельний обробіток на глибину 37-40 см & 121,3 & 88,5 & 104,9 \\
\hline HIP $_{0,5}$ & 5,4 & 8,7 & - \\
\hline
\end{tabular}




\section{СІЛЬСЬКЕ ГОСПОДАРСТВО. РОСЛИННИЦТВО}

Отже, як доводять дані відповідної таблиці, найвищу врожайність зерна (в середньому за два роки) отримали на четвертому варіанті, де проводили чизельний обробіток: тут зібрали по 104,9 ц/га, що доказово перевищило інші варіанти.

Друге місце за відповідним показником за вказаний період посіла оранка на глибину 28-30 см (96,3 ц/га). Стосовно мінімального обробітку, то тут отримали найменшу за роки досліджень урожайність (75,3 ц/га).

\section{БІБЛІОГРАФІЯ}

1. Архипенко Ф. М., Артюоенко О. О., Кухарчук П. І. Агротехнічні заходи підвищення продуктивності та поживності кукурудзи // Вісник аграрної науки. - 2005. - № 6. - С. 15-18.

2. Бовсуновський О. М. Засміченість та врожайність кукурудзи при різній обробці грунту // Агроном. - 2008. - № 1. - С. 132-134.

3. Кравченко Р. В. Основные почвооберегающие обработки почвы под кукурузу. // Аграрная наука. - 2007. - № 6. - С. 9-10.

4. Рудаков Ю. М. Урожайність кукурудзи на зерно в залежності від попередника, обробітку
Висновок. Сільськогосподарським підприємствам, що знаходяться у зоні недостатнього зволоження Лівобережного Лісостепу, за вирощування кукурудзи на зерно варто застосовувати чизельний спосіб основного обробітку на глибину 37-40 см за умови забезпечення ефективного захисту посівів від бур'янів. Такий обробіток грунту варто проводити двічі за ротацію сівозміни у взаємно перпендикулярному напрямку, створюючи так звану сітку на глибині дії робочих органів чизелів.

грунту та добрив у Північному Степу України. // Вісник Дніпропетр. держ. аграрн. ун. - 2003. № 2. - C. 46-48.

5. Танчик С. Г. Основний обробіток грунту під кукурудзу. // Вісник аграрної науки. - 2003. № 1. - C. 28-33.

6. Федоров В. А. Кукуруза: предшественник, обработка почвы. // Кукуруза и сорго. - 2000. № 1. - C. 9 .

7. Шевченко М. К. Мінімалізуємо обробіток грунту. Що маємо? Кукурудза. // Фермерське господарство. - 2006. - № 47. - С. 12-15. 